\title{
Re-narrating Globalization: Hybridity and Resistance in Amores Perros, Santitos and El Jardín del Edén
}

\author{
Brent Smith \\ University of New Mexico, USA
}

\begin{abstract}
:
This paper explores the articulation of resistance to neoliberal globalization in Alejandro González Iñárritu's Amores Perros, Alejandro Springall's Santitos and Maria Novaro's El Jardín del Edén. I argue that this resistance is enunciated within what Homi Bhabha terms 'Third Space', the in-between space of cultural translation and negotiation where notions of an essential national identity are destroyed and a contingent and indeterminate hybrid identity is constructed. Speaking from this hybrid space, these films employ Western cinematic conventions to construct narratives of the disjunctive experience of postcolonial time and space that disrupt the dominant temporality and imaginative geography of Western grand narratives of historical progress and global economic development, while at the same time deterritorializing the space and time of national imagining.
\end{abstract}

[Keywords: resistance, globalization, postcolonial, Amores Perros, Santitos, El Jardín del Edén]

The passage of the North American Free Trade Agreement in 1994 marked what, given the collapse of the communist bloc and thus the last substantial barricade to global capitalist expansion with the end of the Cold War, seemed the inevitable penetration of Western capital and neoliberal ideology into the core of Mexico's social, economic, and political spheres. While NAFTA was surely only the toppling blast in a liberalizing onslaught that had been in progress for some time, it nevertheless seemed to represent the greatest affront to a collective vision for social change. The impact of NAFTA was most heavily felt by the indigenous population and agricultural workers and the most vehement reaction to its exploitative and destructive effects likewise were generated from these sectors; however, the effects of neoliberal globalization have undoubtedly reached beyond these populations to have a transformative effect on the entire social and economic reality of Mexican society. The struggle with this new reality has played out noticeably in Mexican cultural production and particularly in cinematic production. In the three films discussed here - Amores Perros, Santitos, and El Jardín del Edén - this struggle is clear as the effects of globalization, whether the increasing commonality of transnational migration, the shifting socio-economic structures of urban life, or the cultural syncretism of border spaces, play a noticeable role in the films' narratives and in the lives of the films' characters.

For Mexico, as for most of the nations on the global periphery, the effects of globalization have been ambivalent, an ambivalence that Hardt and Negri note as the 'two faces' of globalization. The first, repressive face of globalization consists in the global expansion of capitalist markets, legitimated by an increasingly hegemonic neoliberal ideology, creating the conditions for the exploitation of periphery labor by Western capital. Furthermore, as Martin Hopenhayn notes, the globalization of the market along with the global

Rupkatha Journal on Interdisciplinary Studies in Humanities (ISSN 0975-2935), Vol 2, No 3, 2010

URL of the Issue: http://rupkatha.com/v2n3.php

URL of the article: http://rupkatha.com/V2/n3/RenarratingGlobalization.pdf

(C) www.rupkatha.com 
expansion of communication and media technologies has also led to an increasing division in the periphery nations between individuals and groups integrated into the global cultural and economic circuits, who have more in common with their Western counterparts than others within their own nation, and the non-integrated, those communities on the margins that lack access to the symbolic and economic goods of the global economy (5-9). This division is necessarily elided within a neoliberal discourse that proclaims the triumph of liberalism in its promise of even modernization and equality in the utopia of the market.

On the other hand, globalization has also meant, as Hardt and Negri argue - and this is what they understand as the 'second face of globalization' - the potential for a radically different and more democratic global order contained in "the creation of new circuits of cooperation and collaboration that stretch across nations and continents and allow an unlimited number of encounters" (xiii). In economic terms, there is the possibility, in the increasingly free movement of labor across national borders and the informatization of the economy, of developing international cooperative labor and democratizing knowledge; politically, there is the increasing tendency for resistance and revolutionary movements to organize around democratic principles $(x v-x v i)$. Beyond the economic and political potentialities of globalization, there are also significant implications for cultural production. Specifically, the globalization of the culture industries has opened a space for cultural products from the margins to reach a global audience and has created the conditions for a hybridization of global culture wherein Western cultural symbols become syncretized with those from non-Western cultures, resulting in a new product that cannot be reduced to one or the other. For the film industry, this has meant that Latin American films that otherwise would likely have not reached beyond national borders have increasingly been able to reach a global audience. The Mexican film industry, along with those in other Latin American nations, particularly Argentina and Brazil, have since the 90's, found increasing success in the U.S. and Europe. These films noticeably and self-consciously employ some Hollywood conventions, a fact that has undoubtedly made their success more plausible and which highlights the tendency towards the transnational hybridization of cultural production noted above. Perhaps the most significant example of this tendency is the international success of Alejandro González Iñárritu's Amores Perros. This film's use of a transnational cinematic language to address regional/national experiences with (post)modernity and neoliberal globalization has been the subject of a considerable amount of critical attentioni. However, while Amores Perros certainly represents the most commercially successful film to employ this strategy, it is, I would argue, only one example of an increasing number of films that have articulated resistance to the forces of neoliberal globalization from within a hybrid, transnational space. Two earlier films that, I would suggest, in many ways prefigured this tendency in Amores Perros, while not achieving the same success, were María Novaro's El Jardín del Edén and Alejandro Springall's Santitos. And while Amores Perros has received a fair amount of critical scholarly attention, Santitos and El Jardín del Edén have 
270 Re-narrating Globalization: Hybridity and Resistance in Amores Perros, Santitos and El Jardín del Edén

received little, if anyii. Although Amores Perros has had by far the most international success of the three films, the other two have nevertheless reached an international audience as well and employed a similar hybridization of styles and narratives, and thus occupy a common space with Amores Perros in the transnational film industry.

In this paper, I argue that Amores Perros, along with Santitos and EI Jardín del Edén, employ Western cinematic conventions to communicate local experiences with the effects of neoliberal globalization, articulating resistance to dominant ideologies within what Homi Bhabha refers to as 'Third Space', an in-between space of cultural translation and negotiation where notions of an essential national identity are destroyed and a contingent and indeterminate hybrid identity is constructed. Within this Third Space, these films are then able to destabilize the dominant spatial and temporal logic of both national narration and the hemispheric hegemony of the United States and of neoliberal ideology.

I begin by analyzing the syncretization of Hollywood cinematic conventions and local narratives within the theoretical framework of hybridity, drawing on the work of Bhabha, Canclini, and D'lugo, among others. I then proceed to a discussion of how these films specifically challenge both neoliberal and nationalist ideologies through their destabilization of dominant spatial and temporal logics before concluding with the suggestion that these films can be considered as contributing to the formation of what D. N. Rodowick terms a 'minor cinema'.

\section{Hybridity, Resistance and Transnational Cinema}

Hybridity has become a particularly significant, if loaded, term in social and cultural theory. Employed equally by postcolonial theorists interested in the uneven and syncretic cultural exchange between (neo)colonizer and (neo)colonized and postmodernists proclaiming the end of the division between high and popular cultural forms, the term is often invoked to challenge binary understandings that reproduce Manichean worldviews or elitist power structures. In its postcolonial intonation, hybridity emphasizes the impossibility of returning to any notion of essential national or cultural identity after the colonial encounter, particularly in the present context of social, economic, and cultural globalization. Although the term is often used uncritically to denote a balanced and innocuous mixing of cultures, the process of hybridization is never an even exchange and is always necessarily power-laden, lived, as Robert Stam suggests, as "deeply entangled with colonial violence....alive as a painful, visceral memory" (33). Hybridization in no way erases conflicts between central and periphery nations and cultures. Rather, as Néstor García Canclini argues, it places these conflicts "in a different register, one that is multifocal and more tolerant, and the autonomy of each culture is rethought - sometimes - with smaller fundamental risks" (241). It is this shifting of registers, then, that opens up a new space within which new identities can be constructed and new forms of political resistance articulated. 
For Homi Bhabha, this represents the 'Third Space of enunciation', an indeterminate and liminal space marked by a constant flux of cultural symbols and identities. Bhabha rejects the possibility of articulating a vision for political change from a position restricted by a notion of a unitary and pure cultural identity. He explains:

Fanon's vision of revolutionary cultural and political change as a 'fluctuating movement' of occult instability could not be articulated as cultural practice without an acknowledgement of this indeterminate space of the subject(s) of enunciation. It is that Third Space, though unrepresentable in itself, which constitutes the discursive conditions of enunciation that ensure that the meaning and symbols of culture have no primordial unity or fixity; that even the same signs can be appropriated, translated, rehistoricized and read anew. (55)

Thus, upon Bhabha's reading of Fanon, the struggle for liberation necessarily involves the destruction of the nationalist traditions that were once central to anti-colonial struggles. If we accept Canclini and Bhabha's conceptualizations of hybridization as the determining process of cultural exchange, then, the culturalist position that asserts the need for an 'authentic' national or local culture to resist hegemonic culture becomes untenable. Resistance and the articulation of a vision for political and social change thus only become possible through a rearticulation of dominant cultural symbols and a syncretization of styles and modalities. From inside of a hybrid Third Space, cultural production can execute a sort of political jujitsu as dominant symbols are rearticulated against the (neo)colonial power as an act of resistance. In Latin American and the Caribbean, this process is perhaps most clearly exhibited by the appropriation of the symbol of Caliban, the half-man halfbeast inhabitant of the Caribbean islands from Shakespeare's The Tempest, as a symbol of colonial resistance in the writings of postcolonial authors including Aimé Césaire, Edward Brathwaite, and Derek Walcott, amongst others. As Roberto Fernández Retamar notes, this appropriation involves the rearticulation of a "symbol...that is not entirely ours, that is also an alien elaboration, although...based on our concrete realities" (97).

In the globalized, postmodern world, the film industry has become a noticeable site of this power-laden, contested hybridization and, as such, a space for the articulation of resistance to the more repressive facets of Western-driven neoliberal globalization through the re-articulation of dominant cultural symbols and aesthetic styles. Marvin D'Lugo's discussion of the global success of Latin American co-productions helps to illuminate the specific mechanisms by which films like Amores Perros, Santitos, and El Jardín del Edén appropriate Western cinematic conventions to narrate local experiences and articulate resistance both to entrenched nationalism and neoliberal exploitation. D'Lugo points to the way in which co-produced Latin American films like Solano's Tangos overcome audience ignorance of national issues by utilizing a global cinematic language, employing narrative conventions and styles familiar to Western audiences, to articulate particular national experiences and struggles. However, while these films address 
272 Re-narrating Globalization: Hybridity and Resistance in Amores Perros, Santitos and El Jardín del Edén

national issues, they also deterritorialize national identity; the nation is no longer imagined "as a pristine home, but rather one that is marked and forever altered by the inevitable interaction with a broader economic and social world" ("Authorship" 121). In this way, these hybrid films are able to "challenge the assumptions of the core/periphery model by generating cultural texts that have as their underlying project the co-production of newly emerging cultural identities" (104).

Much like the films D'Lugo discusses, Amores Perros, Santitos, and El Jardín del Edén utilize cinematic conventions that appeal to a global audience to narrate national issues while at the same time deterritorializing national identity and producing a new hybrid cultural identity. Amores Perros employs an easily recognizable non-linear narrative structure - popularized in the U.S. and Europe by Tarantino's Pulp Fiction and Reservoir Dogs, although originating in the silent film era and emerging again in post-WWII European art films, and now a common style even in more 'edgy' Hollywood films - to narrate the experience of different socio-economic classes in Mexico City with the effects of globalization. Furthermore, as Dolores Tierney points out, the film utilizes a variety of cinematic techniques - including the use of multiple film stocks and a hand-held camera - that connect the film's aesthetic style to both American Independent Cinema, whose influence has been increasingly evident even in Hollywood films, and the New Mexican Cinema of the 70's, 80's, and early 90's (106-108). These elements no doubt aid the international reception and circulation of the film. However, they also, as D'Lugo suggests, "help audiences focus on...the contradictions of cultural modernity in contemporary Latin American society" ("Amores Perros" 23). The film's three interweaving narratives each focus on characters representing different socioeconomic classes with the conflictual nature of the relations between these classes conveyed through the spatial and temporal convergence of the separate narratives in the repetition of the car crash scene. The division between the integrated and the non-integrated in the urban space highlighted by the film becomes, through the film's hybridization of narratives and aesthetic style, positioned as part of a larger global phenomenon effecting urban centers in both the core and periphery.

Similarly, Alejandro Springall's Santitos appeals to a global audience through its adherence to the generic conventions of both the road movie - a quintessentially North American genre that traces its roots in Western culture back to the Homeric epic - and those of magic realism - a genre whose transnational popularity is demonstrated by the international success of Alfonso Arau's Como Agua para Chocolate iii $^{\mathrm{in}}$ to narrate the experience of the Mexican migrant, articulated ambivalently both as loss and liberation. The dislocation of Esperanza, the film's protagonist, in the search for her daughter, is experienced as the pain of losing a fixed sense of place and identity - a memory existing only in the ghost of Esperanza's daughter and the fleeting apparitions of Saint Jude - but at the same time the possibility of constructing a new, hybrid identity as part of the diasporic Mexican community in Los Angeles. Through the instigating presence of transnational capitalism, coded 
in the exploitative international sex trade that Esperanza fears her daughter has fallen prey to, Esperanza's dislocation in the film's narrative becomes a representation of the dislocation of Mexican migrants from their homes as a result of the expansion of Western capital (particularly in the aftermath of NAFTA). Just as it becomes impossible for those displaced by the forces of capitalist globalization to reterritorialize their connection with the geographic space of the nation, so Esperanza is unable to find happiness in returning to her home in Veracruz and ultimately relocates to Los Angeles to start a new life.

Much as Amores Perros and Santitos employ formal aesthetics that cross national boundaries, El Jardín del Edén utilizes the generic conventions of the border movie, a genre popular on both sides of the border and encompassing such diverse and historically removed films as Touch of Evil and No Country for Old Men in the U.S. and Espaldas Mojadas and the recent Norteado in Mexico, while at the same time destabilizing the naturalization of the border these films often reproduce. In narrating the diverse experiences of individuals from both Mexico and the U.S. who have each traveled to Tijuana in search of something different, the film challenges both the dominant temporal and spatial logic of the border and allows for a reimagining of the border town as a site of a complex and uneven syncretism and heterogeneity that resists a reductive binary understanding of the relationship between the U.S. and Mexico.

\section{Alternative Temporalities}

All three films, in different ways, play with narrative temporality in ways that allow them to articulate resistance and construct new identities through subverting dominant national and global temporalities, deterritorializing national narration and destabilizing the grand narratives of neoliberal globalization. These films construct alternative temporalities to the dominant temporality manifested as both the homogenous and empty time of the nation and the ordered, progressive time of Western rationality and global capitalist development. Despite neoliberalism's attack on the teleological and utopian rationality of the Latin American planning state, as Hopenhayn points out, neoliberal ideology simply replaces the utopian telos of the planning state with that of the market (150). Thus, neoliberal ideology replicates, in postmodern form, the enlightenment narrative of time as a progressive, ordered whole. Max Horkheimer and Theodor Adorno, in their seminal socio-historical analysis of enlightenment rationality, Dialectic of Enlightenment, identify the classic narrative temporality of enlightenment rationality in their analysis of Homer's Odyssey:

What Odysseus has left behind him has passed into the world of shades: so close is the self to the primeval myth from whose embrace it has wrested itself that its own lived past becomes a mythical prehistory. It seeks to combat this by a fixed order of time. The tripartite division is intended to liberate the present moment from the power of the past by banishing the latter beyond the absolute boundary 
274 Re-narrating Globalization: Hybridity and Resistance in Amores Perros, Santitos and El Jardín del Edén

of the irrecoverable and placing it, as usable knowledge, in the service of the present. (25)

Within the linear view of history this narrative temporality reproduces, the past becomes instrumentalized as knowledge for the present. The cinematic equivalent of this dominant narrative temporality is what Deleuze refers to as the 'movement-image', the classic film narrative which presents time as a linear progression through the protagonist's movement through space and their ability to directly effect their situation through their action. In the movement-image, time exists in a straight line; the present becomes the only real outcome of a chain of events in the past. This narrative temporality is problematized in what Deleuze calls the 'time-image', a new type of film that emerged in Europe after WWII conveying a consciousness of time as labyrinthine rather than linear, with multiple virtual pasts, presents, and futures existing simultaneously. Though Deleuze's binary distinction here is somewhat reductive - as David Martin-Jay demonstrates, most films exist in a hybrid form in which time is to varying degrees deterritorialized into a labyrinthine form or reterritorialized into a linear narrative - it does provide a way of understanding how the films discussed here are able, to some extent, to deterritorialize the dominant temporality of enlightenment rationality and global capital.

This same enlightenment conceptualization of history, reproduced in the linear narrative of the movement-image, becomes central to the imagining of national identity within what Anderson calls the 'homogenous, empty time' of the nation (33). Martin-Jones, drawing on Deleuze's work on the movement-image and time-image and Bhabha's notion of the double time of the nation, argues that "jumbled, fragmented, multiplied or reversed film narrative...can be interpreted as an expression of the difficulty of narrating national identity at a time of historical crisis or transformation" (1). For MartinJones, the hybrid movement-image/time-image films that result from this crisis in national identity involve a constant oscillation between the movementimage's plane of organization and the time-image's plane of consistency (26). This instability in national narration coincides with Bhabha's conception of the splitting between the pedagogical and performative time of the nation. For Bhabha, national narration involves "a split between the continuist, accumulative temporality of the pedagogical, and the repetitious, recursive strategy of the performative" through which "the conceptual ambivalence of modern society becomes the site of writing the nation" [emphasis original] (209). As Martin-Jay argues, the constant performative reconceptualization of the past in the present can be understood as the attempt to reterritorialize national identity, reasserting the linearity of national time. To varying degrees, the films discussed here disrupt the perpetual performance of national identity through their deterritorializing narrative temporalities, through which "it is sometimes possible to glimpse the performance of national identity as a repetition of difference" (35).

In Amores Perros, a labyrinthine temporality is constructed through the film's non-linear narrative structure that jumps around in time and between 
narratives. This narrative strategy, in Tierney's words, "ruptures the timespace continuum of classical narrative" (105). The effect is to dislodge the events of the film from a plane of causality linking past, present, and future in a straight line, instead presenting a multi-layered temporality without a necessarily true past or future and thus destabilizing the linear temporality of both the nation and global capital. Unlike the typical movement-image, in which a flashback structure is used that "begins with the end of the story and flashes back to the 'beginning', thereby establishing a teleological progression and a false origin from which the narrative stems" (Martin-Jay 28), Amores Perros's point of temporal convergence, the car crash in which the film's main characters are violently thrown into contact, with each repetition, opens up to alternative pasts and futures in the form of the separate narratives into which the film diverges. The film opens just minutes before this point of convergence, as Octavio and his friend Jorge are the pursued in a high-speed car chase. After several near-crashes, Octavio runs a red light and smashes into the car driven by Valeria. The film then cuts back in time to the beginning of Octavio and Susana's story. However, upon the next repetition of the crash, we do not proceed into Octavio and Susana's future, but rather the past of Daniel and Valeria. While there is some temporal reterritorialization in the linear progression of Daniel and Valeria's story up through and after the next repetition of the car crash, this linearity is disrupted by the imposition of scenes from El Chivo's story that occur outside the temporal framework of the Daniel and Valeria narrative. We are then again, at the terminus of this narrative, transported abruptly back before the crash where El Chivo's story resumes. Here, the divergent narratives can be read as representing alternative pasts and futures within a multi-layered labyrinthine temporality, rejecting the notion of a singular origin and future along the linear timeline of the dominant national and transnational temporalities. The repetition of the car crash also serves to destabilize the neoliberal narrative of the progressive nature of the time of global capital as the characters, occupying differing class positions, become inevitably tied together in a violent and conflictual way. Rather than being experienced as progress and development, the economic impact of globalization, recognized in the widening gap between the socioeconomic classes the characters represent, is experienced instead as a recurring trauma in a way that challenges the neoliberal temporality of even development.

The character of El Chivo in the film presents a particularly imposing disruption to national narration through exposing the split between the pedagogical and performative time of the nation. El Chivo exists as a ghostly, liminal figure, residing in the interstices between the 'homogenous, empty time' and the zero-time of the nation. El Chivo's past as a guerilla, which we first learn of through a conversation between Gustavo and Leonardo, invokes to an extent the rhetorical figure of revolution in the PRI's revolutionary nationalism's imagining of the national past. However, as the figure of a revolution opposed to the order embodied by the $\mathrm{PRI}$ and the rise of the bourgeois during the 60's, he represents a challenge to the pedagogical function of revolution as a rhetorical figure. In the present, El Chivo's life on 
276 Re-narrating Globalization: Hybridity and Resistance in Amores Perros, Santitos and El Jardín del Edén

the margins of national society, not integrated into the national or global economic or communication circuits, challenges the narrative of modernization and development, thus constituting a repetition of difference in the performative time of the nation.

In Santitos, the dominant temporality of the nation and neoliberal ideology is subverted through the presence of the ghost of Esperanza's daughter. As Anna Powell argues, "ghosts conflate past and present as they linger to repeat their own present, refusing to let it be past...compel[ling] present-day characters to abandon contemporaneity and to experience the history of others by enforced overlay" (qtd. in Martin-Jay 69). The ghost of Esperanza's daughter can be read as an incorporeal reminder of the dislocation of individuals by global capitalist expansion, an expansion represented in the film through the exploitation of Mexican sexual labor by the international sex trade, highlighting the double exploitation of Mexican women by global capitalism and patriarchal power structures. The presence of the ghostly figure of Esperanza's daughter refuses the instrumentalization of the past, instead insisting on its constant reliving as a real, contemporary experience. In the daughter's repetition of the promise that she will always be with her mother, the persistence of the past as alive in the present - the past that is as opposed to the past that was - is guaranteed. However, the ghostly presence also symbolizes the impossibility of returning to an essentialized past notion of national and cultural identity. Rather, the past can only exist in the present in a liminal state, in which it is relived but cannot be returned to. It is particularly significant here that the body of Esperanza's daughter can never be uncovered. The coffin in which the body is supposed to lie is sealed because, the doctor claims, the girl died of an "unknown virus" and they can't risk its spread, and Esperanza's attempts to dig up the body in the graveyard are thwarted by the morgue workers. The absence of a body denies any possibility of closure for Esperanza and becomes the motivating force for her journey that ultimately results in a reconstruction of her identity. The film also subverts dominant temporality through its use of religious symbols and institutions to express the contradictions and struggles in the transition to modernity. Much like the ghost of her daughter, E[sp]pseranza's devout religiousness represents an attachment to a traditional past that is challenged and reconstructed through her experiences with the forces of modernization. The tension between tradition and modernization is perhaps most evident in a scene in which Esperanza calls Padre Salvador from Tijuana to tell him of all that has happened since their last contact. When Esperanza first asks to confess her sins, Salvador initially refuses, telling her that the church does not permit long-distance confessions. This humorous moment foregrounds the tension between the notion of a traditional religious community tied to geographic location and a postmodern global society in which global communication networks allow for the formations of communities not restricted by geography. Ultimately, however, Esperanza does not reject religion in order to move into modernity in a way that would suggest moving beyond the pre-modern past. Instead, this past remains alive in the present in 
a reconstructed form as Esperanza retains a connection to religion through her relationship with the Angel of Justice.

Like Amores Perros, El Jardín del Edén plays with narrative temporality through a non-linear narrative structure. However, unlike the labyrinthine and divergent narrative temporality of Amores Perros, El Jardín del Edén employs a circular narrative structure. Although the film's narrative seems to follow a linear progression, this linear temporality is complicated by the circular nature of the characters' cross-border journeys, which follow a pattern of return and repetition as the characters return north or south of the border only to repeat their journey. The film opens with Felipe standing on the Mexican side of the border, looking longingly across, and ends with a similar image of Felipe, though his physical appearance has clearly been altered by his experiences throughout the film, once again standing at the border, gazing across. This circular narrative structure is, as Andre Noble notes, common among films of the border-film genre in Mexico. Noble argues, however, that what differentiates El Jardín del Edén from other Mexican border films is its decentralized narrative structure, which disperses narrative identification onto several female characters instead of centralizing it on a single male protagonist. The impact of this decentralization, in addition to the circular narrative structure, is to challenge the image of the border as demanding the straightforward, linear response of crossing it (194-196). Adding to Noble's analysis, I would suggest that this linear logic demanded by the border can be understood in terms of a linear spatialization of history in the dominant spatiotemporal logic, in which the U.S. represents the telos of historical development and thus the northwards movement across the border in space becomes a linear movement in time towards a more advanced stage of historical development. By subverting the linear logic of the border, then, El Jardín del Edén also subverts the dominant spatio-temporal logic of U.S. hegemony and global capitalist development.

\section{Re-imagined geographies}

These three films also both articulate resistance to neoliberal globalization and subvert national narration through their destabilizing of the imaginative geographies that are central to the hemispheric hegemony of the U.S. and neoliberal ideology, as well as the imaginative geography of the national community. In the U.S., and more generally Western, imagination, the border between the U.S. and Mexico marks a geographic division that structures Western knowledge of Latin America and creates Latin America as a primitive, underdeveloped space existing in a state of stunted historical growth. This image legitimates U.S. and Western intervention, both in the form of direct political intervention and of economic expansion, as necessary to modernize Latin America, rescuing it from savagery and bringing into the civilized world. Here, the colonial ideology of the West as having the paternalistic responsibility to guide the colonial world into modernity is reproduced in neocolonial form. While subverting this neocolonial imaginary geography, these films also destabilize the imagining of Mexico as a homogenous and unitary geographical space and a community that, to use 
Anderson's words, "is always conceived as a deep, horizontal comradeship" despite the material conditions of inequality and exploitation that may exist (7), thus deterritorializing the connection of identity to geographic space and challenging a Manichean representation of conflicts between the U.S. and Mexico, North and South, center and periphery.

The Mexico-U.S. border itself becomes one of the most important figures in the U.S. and Western geographic imaginary as it becomes a fixed, essentialized division marking a natural border between spaces; it's contingent nature as the product of particular social, economic, and political power relations is elided. In El Jardín del Edén, this conceptualization is challenged through a denaturalizing and deessentializing of the border as a division between the U.S. and Mexico. The border town of Tijuana is represented as a hybrid space in which cultural symbols from both the U.S. and Mexico coexist and merge and to which individuals come for a variety of reasons, none of which correspond to the image of Tijuana as either a dystopian space of rampant crime or as a casino where North Americans come to satisfy their base and prohibited desires. The border itself also becomes a stage for many of the events in the film and one that becomes deesentialized as a dividing line or marker of absolute difference. The first time we see Felipe standing on the beach at the border, the camera's focus is drawn to the space beyond the terminus of the border fence, in which any visible distinction between the two sides disappears as the sand slopes into the sea. This focus denaturalizes the existence of the border, making it appear as an arbitrary division rather than an absolute one. An overhead shot of the border further emphasizes this arbitrariness as the contiguity between the natural landscapes on either side of the border make the fence appear oddly out of place, disturbing the beauty of the beach scene. In another scene, we see a little-league baseball game taking place right across the border on the Mexican side as two border patrol officers look on. When one of the players hits a home run, both of the border patrol officers erupt in celebration and exchange high-fives. Here, the geographic divide of the border collapses in the spontaneous interaction of individuals across this space, emphasizing the border's arbitrarily imposed character. The geographic imaginary of the U.S. and Mexico is likewise subverted in Santitos, as Esperanza's cross-border migration destabilizes the spatial division between the two nations and constructs a hybrid space marked by a contingent cultural solidarity rather than a natural connection of cultural to national space. In the final scene of the film, as Esperanza chips away, with a pick axe, the bathroom wall and mirror, where the ghost of her daughter resides, from the rest of her house and tows it across the border on her journey to Los Angeles with her lover, the Angel of Justice, she both challenges the fixity of national and cultural identity and subverts the geographic division between the U.S. and Mexico by forcing a spatial syncretization of the two. The final tracking shot of the bathroom wall, towed behind Angel's truck, traveling through the Mexican desert towards the border thus becomes a perfect visual metaphor for hybridity and the construction of a new deterritorialized cultural identity not tied to geographic location. 
As Canclini points out, the urban center becomes an especially significant space for hybridization, as it represents a "scheme with a heterogeneous symbolic offering renewed by a constant interaction of the local with the national and transnational networks of communication" (208). In Amores Perros and Santitos, urban centers on both sides of the border Mexico City in Amores Perros and Los Angeles in Santitos - become particularly important as spaces of cultural syncretism and negotiation and sites for the subversion of national and transnational imaginary geographies. In Amores Perros, the representation of urban space becomes a vehicle for exposing the inequalities between economic classes in Mexico City and the stark gap between the integrated and the non-integrated. As D'Lugo points out, the Mexico City of the film is "characterized by the continuous juxtapositions between the modern and primitive, between a glamorous world of televisual images and the leitmotifs of animalistic violence" ("Amores Perros" 224). The existence of these contrasting juxtapositions challenges the market's promise of egalitarian development and equal access to symbolic and economic products. These inequalities become visualized in a particularly poignant way in a scene where El Chivo observes Luis, the businessman Gustavo has paid him to kill. El Chivo's tattered clothes, unkempt beard and hair, and his shopping cart stand in stark contrast to the idealized bourgeois urban space of windowed skyscrapers and European luxury cars that surrounds him. Curiously, he goes seemingly unnoticed by the wealthy passers-by, which serves to highlight the way in which the underclass is made invisible by the spatial logic of the decentralized postmodern city. The car crash, in representing the violent spatial convergence of the individuals from different classes, dramatizes the conflictual nature of class relations in the global city and subverts both the national mythology that posits the interests of the bourgeois as that of the entire nation, in Roland Barthe's words, "obliterat[ing] its name in passing from reality to representation, from economic man to mental man" (138) and the neoliberal myth of capitalist globalization as a benevolent vehicle of egalitarian and equal economic development.

It should be noted, though, that there is some ideological ambivalence in the representation of violence in the urban space within the film. As Ignacio Sánchez-Prado notes, violence is seen in the film largely as a product of moral decay, disconnected from social and political structures (40-45). However, this elision of the socio-political causes of violence is somewhat problematized by a kind of class structure that exists in the violence of $\mathrm{El}$ Chivo, whose assassinations are commissioned, at least in the hit on Luis, by bourgeois individuals against other bourgeois individuals. Thus, El Chivo's violence, unlike that of the other characters, can be disconnected from a sense of personal morality and instead connected to an exploitation of working class labor by Mexico's emerging bourgeois. This complexity further emphasizes the significance of El Chivo's character. As D'Lugo notes, El Chivo is "notable as the only character in the film with a past as well as the hint of a future" and as the only character to reject "domestic bliss as the ultimate goal for which to strive" ("Amores Perros" 225-26). Thus, ultimately 
280 Re-narrating Globalization: Hybridity and Resistance in Amores Perros, Santitos and El Jardín del Edén

El Chivo's class position allows for the development of a consciousness not afforded the other characters - one capable of imagining the possibility of a different future.

In Santitos, the urban space of Los Angeles is used to both destabilize the binary oppositions of First and Third World and to construct a space of cultural hybridization wherein the Mexican diasporic community is able to construct a new identity and articulate resistance to conditions of inequality and injustice. The Los Angeles of the film is far removed from the idealized urban utopia of many Hollywood films, bearing a much stronger similarity to Tijuana than to the typical glittery image of LA. In the first scene after Esperanza arrives in LA, we are immediately confronted by hoards of unemployed immigrants searching desperately and unsuccessfully for employment. In this way, the U.S. city appears much more like an urban center in the 'Third World' than a modernized 'First World' metropolis. This lack of distinction destabilizes the First/Third World opposition. This division is further destabilized in the imagining of Los Angeles as a hybrid space in which new identities are constructed and resistance articulated. In one scene, we witness a Lucha Libre match in which a wrestler called the Angel of Justice - who will later become Esperanza's lover - battles and defeats a wrestler known as La Migra, or Border Patrol. Here, Lucha Libre, itself a hybridization of U.S., European, and indigenous influences, is transformed into a form of protest against the inequality in the supposedly free movement across the border, as seen in the contrast between the ease with which Scott Haines, the U.S. judge, is able to travel back and forth between California and Tijuana, and the need for Esp[e]aranza to be smuggled into the U.S. with Haines' assistance.

\section{Conclusion: Towards a Minor Cinema}

D. N. Rodowick, drawing from Deleuze's writings on cinema and Deleuze and Guattari's notion of a 'minor literature', has coined the term 'minor cinema' to denote a revolutionary cinema utilized by marginal groups to construct a new identity. Through this 'revolutionary' cinema, the global margins are able to speak through "tak[ing] a major cinematic voice and mak[ing] a minor use of it, making it stutter or stammer" (Martin-Jay 36). Similarly, Bhabha speaks of the way in which marginalized or minority groups make use of the dominant voice in a minor way, contributing to a 'minority discourse' that adds to the dominant discourse without ever adding up (222-223). While Bhabha and Rodowick are interested in how these texts become part of a minority national discourse, I think that, considering the declining centrality of the nation-state and the restructuring of global power structures, we can use these concepts to think about how these films can both construct new identities that subvert national imagining and challenge the dominant ideologies of new transnational power structures, adding to a transnational minority discourse. In this way, we can begin to think of the films discussed here, along with many other Mexican and Latin American films that have staked out a place in the hybrid space of global cinema, as forming a transnational 'minor cinema' that speaks from the margins to contest the more repressive aspects of capitalist globalization, 
answering Canclini's call for a cultural politics that affirms heterogeneity and solidarity to augment the popular protest movements against the WTO, IMF, and World Bank.

\section{Notes}

'See Tierney 103-110; D'Lugo, “Amores Perros”; and Sánchez-Prado 46-50
i One notable exception is Andrea Noble's eloquent analysis of El Jardín del Edén in
"'Yéndose por la tangente': The Border in María Novaro's El Jardín del Edén."
iii Unlike Como Agua para Chocolate, however, Santitos avoids reproducing the clichéd image
of a romanticized pre-modern Mexico

Works Cited

Anderson, Benedict. Imagined Communities: Reflections on the Origin and Spread of Nationalism. New York: Verso, 2006. Print.

Barthes, Roland. Mythologies. Trans. Annette Lavers. New York: Hill and Wang, 1972. Print.

Bhabha, Homi. The Location of Culture. London and New York: Routledge, 2004. Print.

Canclini, Néstor García. Hybrid Cultures: Strategies for Entering and Leaving Modernity. Trans. Christopher L. Chiappari and Silvia L. López. Minneapolis: University of Minnesota Press, 2005. Print.

D'Lugo, Marvin. "Amores Perros / Love's a Bitch." The Cinema of Latin America. Eds. Alberto Elena and Marina Díaz López. London: Wallflower Press, 2003. 221-229. Print.

---. "Authorship, Globalization, and the New Identity of Latin American Cinema: From the Mexican 'Ranchera to Argentinian 'Exile'." Guneratne and Dissanayake 103-125. Print.

Deleuze, Gilles. The Movement-Image. Trans. Hugh Tomlinson and Barbara Habberjam. Minneapolis: University of Minnesota Press, 1986. Print.

Hardt, Michael, and Antoni Negri. Multitude: War and Democracy in the age of Empire. New York: The Penguin Press, 2004. Print.

Hopenhayn, Martín. No Apocalypse, No Integration: Modernism and Postmodernism in Latin America. Trans. Cynthia Margarita Tompkins and Elizabeth Rosa Horan. Durham, NC: Duke University Press, 2001. Print.

Horkheimer, Max, and Theodor W. Adorno. Dialectic of Enlightenment: Philosophical Fragments. Trans. Edmund Jephcott. Ed. Gunzelin Schmid Noerr. Stanford, CA: Stanford University Press, 2002. Print.

Guneratne, Anthony R., and Wimal Dissanayake, eds. Rethinking Third Cinema. New York: Routledge, 2003. Print.

Martin-Jones, David. Deleuze, Cinema and National Identity: Narrative Time in National Contexts. Edinburgh: Edinburgh University Press, 2006. Print.

Noble, Andrea. "'Yéndose por la Tangente': The Border in María Novaro's El Jardín del Edén." Journal of Iberian and Latin American Studies 7.2 (2001): 191-202. Academic Search Complete. Web.

Retamar, Roberto Fernández. "Caliban: Notes Toward a Dicussion of Culture in Our America." The Latin American Cultural Studies Reader. Eds. Ana Del Sarto, Alicia Ríos and Abril Trigo. Durham, NC: Duke University Press, 2004. 83-99. Print.

Sánchez-Prado, Ignacio M. "Amores Perros: Exotic Violence and Neoliberal Fear." Journal of Latin American Cultural Studies 15.1 (2006): 39-57. Print.

Stam, Robert. "Beyond Third Cinema: The Aesthetics of Hybridity." Guneratne and Dissanayake 31-48. Print.

Tierney, Dolores. "Alejandro González Iñárritu: Director Without Borders." New Cinemas: Journal of Contemporary Film 7.2 (2009): 101-117. Print.

Brent Smith is Teaching Assistant, University of New Mexico.

Email:bsmith888@gmail.com 